\title{
PENGARUH KONSENTRASI GEL THEOBROMINE TERHADAP KETAHANAN KEKERASAN PERMUKAAN EMAIL GIGI DESIDUI
}

\author{
Indah Lestari Vidyahayati*, Rinaldi Budi Utomo**, Indah Titien Soeprihati*
}

Keywords:

Theobromine,

hardness resistance,

primary teeth enamel

\section{ABSTRACT}

Background: Primary tooth enamel are susceptible to damage because it has a low thickness so it requires preventing treatments to maintain. Theobromine, an alkaloid of the methylxanthine group, has been shown to improve crystallinity and resistance of enamel apatite solubility to acids. The enamel resistance to acid requires a series of test of physical properties, by measuring at microhardness. This study analyzes the effect of theobromine gel consentration on the hardness resistance of primary incisors enamel surfaces.

Method: Twenty-five specimens were divided into 5 groups of topical application of theobromine gel with concentrations of $1 \%, 2 \%, 3 \%, 4 \%$, and $5 \%$, and then immersed in acidic solution. Results were analyzed using one-way ANOVA

Result: One-way ANOVA test showed significant differences in the increase and decrease in enamel microhardness after the application of theobromine gel and acid immersion $(p<0.05)$. The highest values of increase and decrease in enamel microhardness (764,74 $\pm 187,08 \mathrm{VHN}$ and $457,18 \pm 54,37 \mathrm{VHN}$, respectively) was shown in $5 \%$ group of theobromine gel.

Conclusion: The higher theobromine gel concentration, the higher the microhardness value but unable to maintain the enamel resistance against acid. The $5 \%$ theobromine gel concentration was the most effective one to increase the microhardness of primary teeth enamel.

\section{PENDAHULUAN}

Struktur email gigi desidui mengandung lebih banyak komponen organik bila dibandingkan mineral anorganik hidroksiapatit, dan tidak tahan terhadap asam ${ }^{1,2}$. Hal ini menyebabkan gigi desidui mudah mengalami kerusakan, sehingga diperlukan suatu upaya pencegahan untuk mempertahankan gigi desidui ${ }^{3,4}$.

Paparan asam di bawah titik kritis $\mathrm{pH} \mathrm{5,5}$ pada email gigi dalam waktu lama dapat merusak struktur dan melonggarkan ikatan sehingga ukuran kristal email menjadi lebih kecil 5 . Hal ini akan menyebabkan kerusakan struktur gigi yang ditandai dengan melemahnya email.

Salah satu upaya mencegah kerusakan email gigi desidui yaitu melalui topikal aplikasi dengan fluor. Penggunaan fluoride terdapat pro dan kontra karena beberapa efek samping, juga perlunya pengawasan, dosis, dan teknik yang tepat ${ }^{6}$.

Seiring perkembangan keilmuan, diperlukan alternatif bahan yang lebih aman dengan efektifitas yang sama sebagai pengganti fluor, salah satunya adalah theobromine. Theobromine sebagai alkaloid utama golongan methylxanthine dapat meningkatkan kristalinitas dan resistensi kelarutan apatit pada email terhadap asam $^{7,8}$. Senyawa theobromine meningkatkan ketahanan email terhadap asam melalui reaksi interstitial ${ }^{9}$. Ketahanan email terhadap asam memerlukan serangkaian pengujian sifat fisik, salah satunya yaitu kekerasan mikro permukaan yang dihasilkan.

Penelitian terdahulu terhadap theobromine masih terbatas pada perendaman dalam laru-

* Program Studi IImu Kedokteran Gigi Klinik Fakultas Kedokteran Gigi Universitas Gadjah Mada , **Departemen Kedokteran Gigi Anak Fakultas Kedokteran Gigi Universitas Gadjah Mada

Korespondensi: indahlestarivi.drg@gmail.com 
tan. Saat ini penelitian dengan sediaan gel secara topikal aplikasi dengan berbagai variasi konsentrasi belum banyak dilakukan. Penelitian menggunakan sediaan gel diharapkan dapat memberikan efektifitas theobromine yang lebih baik.

\section{METODE PENELITIAN}

Penelitian ini adalah penelitian eksperimental laboratoris menggunakan 25 gigi insisivus desidui, dengan kriteria morfologi gigi normal, tidak terdapat karies, fraktur, abrasi, erosi, dan tidak terdapat restorasi. Mahkota gigi ditanam di dalam resin epoksi, dan dilakukan polishing dengan kertas silicone carbide grit 5000 di bawah air mengalir untuk mendapatkan permukaan yang datar dan halus ${ }^{10}$. Objek dibagi menjadi 5 kelompok perlakuan yang diambil secara acak, yaitu kelompok $1 \%, 2 \%, 3 \%, 4 \%$, dan $5 \%$ gel theobromine.

Saliva buatan disusun dari $\mathrm{K}_{2} \mathrm{HPO}_{4}$ 0,2 gr; $\mathrm{Ca}_{3} \mathrm{PO}_{4}$ 0,3 gr; KCNS 0,3 gr; $\mathrm{NaCl} 0,7 \mathrm{gr} ; \mathrm{KCl}$ 1,2 gr; Urea 0,13 gr; $\mathrm{NaHCO}_{3} 1,5 \mathrm{gr}$; dengan pH 6,8 (kondisi netral) dan pH 5 (kondisi asam) yang disesuaikan dengan $\mathrm{KOH}$. Pembuatan gel theobromine konsentrasi $1 \%, 2 \%, 3 \%, 4 \%$, dan 5\% menggunakan formula standar gel berbasis $\mathrm{Na}-\mathrm{CMC}$ dalam \% b/b ${ }^{11}$. Pengukuran kekerasan mikro dilakukan dengan micro Vickers hardness tester dengan beban $50 \mathrm{gf}$ selama 10 detik.

Setiap kelompok sampel dilakukan pengukuran kekasaran dan kekerasan mikro email kondisi awal, kemudian dilakukan aplikasi topikal gel theobromine selama 4 menit, direndam dalam artifisial saliva $\mathrm{pH}$ 6,8 dan disimpan dalam inkubator selama 60 menit dan selanjutnya diukur kekasaran dan kekerasan mikro email. Setiap kelompok selanjutnya dilakukan perendaman dalam larutan artifisial saliva $\mathrm{pH}$
5 dan dimasukkan inkubator selama 30 menit. Pengukuran kekasaran dan kekerasan mikro permukaan kembali dilakukan setelahnya.

Data penelitian dilakukan analisis menggunakan One-way ANOVA yang dilanjutkan dengan uji Post hoc LSD.

\section{HASIL PENELITIAN}

Kekerasan mikro permukaan email terjadi peningkatan setelah dilakukan topikal aplikasi dengan gel theobromine pada semua kelompok perlakuan. Perubahan kekerasan mikro tertinggi terlihat pada kelompok konsentrasi $5 \%(764,74 \pm 187,08 \mathrm{VHN})$ dan paling rendah pada konsentrasi $4 \%(354,78 \pm 26,71 \mathrm{VHN})$. Setelah dilakukan perendaman dalam larutan asam, kekerasan mikro paling tinggi pada konsentrasi 5\% (457,18 $\pm 54,37 \mathrm{VHN})$ dan paling rendah pada konsentrasi $4 \%(341,32 \pm 33,20$ VHN) (lih.Tabel 1).

Tabel 1. Rerata dan standar deviasi perubahan kekerasan mikro permukaan email gigi incisivus desidui kondisi awal, setelah dilakukan top

\begin{tabular}{ccccc}
\hline $\begin{array}{c}\text { Konsen } \\
\text { trasi }\end{array}$ & $\mathrm{N}$ & $\begin{array}{c}\text { Kekerasan } \\
\text { kondisi awal } \\
\left(\mathrm{kg} / \mathrm{mm}^{2}\right)\end{array}$ & $\begin{array}{c}\text { Kekerasan } \\
\text { setelah } \\
\text { aplikasi } \\
\text { theobromine } \\
\left(\mathrm{kg} / \mathrm{mm}^{2}\right)\end{array}$ & $\begin{array}{c}\text { Kekerasan } \\
\text { setelah } \\
\text { direndam } \\
\text { asam } \\
\left(\mathrm{kg} / \mathrm{mm}^{2}\right)\end{array}$ \\
\hline $1 \%$ & 5 & $449,66 \pm 36,63$ & $554,21 \pm 46,72$ & $414,46 \pm 72,52$ \\
$2 \%$ & 5 & $487,01 \pm 23,56$ & $573,54 \pm 19,22$ & $446,75 \pm 52,79$ \\
$3 \%$ & 5 & $317,74 \pm 37,38$ & $477,13 \pm 94,09$ & $406,26 \pm 56,42$ \\
$4 \%$ & 5 & $288,62 \pm 15,50$ & $354,78 \pm 26,71$ & $341,32 \pm 33,20$ \\
$5 \%$ & 5 & $396,52 \pm 92,08$ & $764,74 \pm 187,08$ & $457,18 \pm 54,37$ \\
\hline
\end{tabular}

Hasil uji Anova satu jalur pada Tabel 2 menunjukkan $p<0,05$. Hal ini menunjukkan bahwa konsentrasi topikal aplikasi gel theobromine dapat mempengaruhi kekerasan mikro permukaan email gigi insisivus desidui. Hasil juga menunjukkan bahwa perendaman dalam larutan asam mempengaruhi kekerasan mikro permukaan email gigi insisivus desidui. Uji post hoc LSD (Least Significant Difference) untuk mengetahui kelompok konsentrasi mana 
yang berbeda secara bermakna diantara kelima kelompok perlakuan (lih. Tabel 3).

Tabel 2. Hasil Uji Anava satu jalur pada kekerasan mikro permukaan email gigi incisivus desidui setelah topikal aplikasi gel theobromine dan setelah perendaman asam

\begin{tabular}{lcccc}
\hline & $\bar{X}$ & $\mathrm{df}$ & $F$ & $p$ \\
\hline $\begin{array}{l}\text { Antar kelompok } \\
\text { ssd theobromine }\end{array}$ & 302942,457 & 4 & 9,083 & 0,000 \\
\hline $\begin{array}{l}\text { Antar kelompok ssd } \\
\text { asam }\end{array}$ & 243475,348 & 4 & 6,795 & 0,001 \\
\hline
\end{tabular}

Tabel 3. Uji post hoc LSD rerata perubahan kekerasan mikro permukaan email gigi incisivus desidui setelah topikal aplikasi gel theobromine

\begin{tabular}{cccccc}
\hline Konsentrasi & $1 \%$ & $2 \%$ & $3 \%$ & $4 \%$ & $5 \%$ \\
\hline $1 \%$ & & 0,758 & 0,354 & 0,514 & $0,000^{*}$ \\
$2 \%$ & 0,758 & & 0,222 & 0,728 & $0,000^{*}$ \\
$3 \%$ & 0,354 & 0,222 & & 0,122 & $0,002^{*}$ \\
$4 \%$ & 0,514 & 0,728 & 0,122 & & $0,000^{*}$ \\
$5 \%$ & $0,000^{*}$ & $0,000^{*}$ & $0,002^{*}$ & $0,000^{*}$ & \\
\hline
\end{tabular}

Hasil uji post hoc dengan LSD menunjukkan adanya perbedaan bermakna dengan nilai $p<0,05$. Pada kelompok setelah topikal aplikasi gel theobromine terdapat perbedaan yang bermakna konsentrasi 5\% dibanding semua kelompok konsentrasi. Kelompok konsentrasi gel theobromine 5\% merupakan kelompok yang paling efektif dalam meningkatkan kekerasan mikro permukaan email gigi insisivus desidui.

Tabel 4. Uji post hoc LSD rerata perubahan kekerasan mikro permukaan email gigi incisivus desidui setelah perendaman asam

\begin{tabular}{cccccc}
\hline Konsentrasi & $1 \%$ & $2 \%$ & $3 \%$ & $4 \%$ & $5 \%$ \\
\hline $1 \%$ & & 0,831 & 0,263 & $0,048^{*}$ & $0,011^{*}$ \\
$2 \%$ & 0,831 & & 0,361 & 0,073 & $0,007^{*}$ \\
$3 \%$ & 0,263 & 0,361 & & 0,349 & $0,001^{*}$ \\
$4 \%$ & $0,048^{*}$ & 0,073 & 0,349 & & $0,000^{*}$ \\
$5 \%$ & $0,011^{*}$ & $0,007^{*}$ & $0,001^{*}$ & $0,000^{*}$ & \\
\hline
\end{tabular}

Hasil pada Tabel 4 memperlihatkan perbedaan bermakna antara kelompok $4 \%$ dengan kelompok $1 \%$, dan perbedaan bermakna pada konsentrasi $5 \%$ dengan semua kelompok konsentrasi $(p<0,05)$. Hal ini menunjukkan terdapat penurunan kekerasan pada kelompok konsentrasi $4 \%$ dibandingkan kelompok kon- sentrasi $1 \%$, dan penurunan kekerasan pada kelompok konsentrasi 5\% terhadap kelompok konsentrasi lain setelah dilakukan perendaman dalam larutan asam.

\section{DISKUSI}

Hasil uji Anova satu jalur pada Tabel 3 dengan nilai $p<0,05$ menunjukkan bahwa aplikasi gel theobromine berpengaruh bermakna dalam meningkatkan kekerasan mikro permukaan email gigi desidui. Hasil uji post hoc LSD menunjukkan bahwa topikal aplikasi gel theobromine konsentrasi 5\% paling efektif pengaruhnya dalam meningkatkan kekerasan mikro email gigi. Hal ini kemungkinan disebabkan oleh kenyataan bahwa semakin tinggi konsentrasi theobromine yang diberikan maka semakin besar ukuran kristal hidroksiapatit email gigi yang akan meningkatkan tingkat kekerasannya ${ }^{1}$.

Hasil uji Anova satu jalur pada Tabel 2 menunjukkan nilai $p<0,05$ yang berarti bahwa perendaman dengan larutan suasana asam berpengaruh bermakna menurunkan kekerasan mikro email gigi setelah dilakukan topikal aplikasi gel theobromine. Uji post hoc LSD menunjukkan penurunan kekerasan mikro yang paling banyak setelah perendaman dalam asam juga terlihat bermakna pada konsentrasi $5 \%$, dan pada konsentrasi $4 \%$ dibandingkan dengan 1\%. Berdasarkan hasil tersebut terlihat bahwa theobromine tidak cukup dalam mempertahankan kekerasan email gigi terhadap paparan asam. Penelitian ini menunjukkan bahwa theobromine mampu meningkatkan kekerasan email, namun tidak berkontribusi mempertahankan kekerasan setelah perendaman asam².

Peningkatan kekerasan mikro email gigi dipengaruhi oleh susunan dan ukuran kristal 
apatit, serta adanya sejumlah mineral ${ }^{12,13}$. Kekerasan permukaan email akan meningkat seiring dengan meningkatnya pembentukan kristal apatit baru yang mengandung sejumlah xanthine teralkilasi (theobromine) ${ }^{14}$. Terjadi reaksi interstitial saat ion-ion di dalam senyawa theobromine masuk ke dalam kristal apatit ${ }^{9}$. Perubahan mineral dalam kristal apatit akan merubah sifat fisik susunan kristal apatit menjadi lebih padat. Peningkatan kepadatan kristal apatit di dalam permukaan email gigi dapat meningkatkan regangan sehingga kristal apatit sulit dipecah. Hal ini terlihat berupa peningkatan kekerasan mikro permukaan email gigi ${ }^{15,16}$.

Kadar keasaman $(\mathrm{pH})$ saliva yang mampu melepaskan mineral email berada pada titik kritis di bawah 5,5. Pada suasana asam tersebut, akan terjadi penarikan ion hidroksil $(\mathrm{OH}-)$ dari email gigi ke dalam saliva ${ }^{17}$. Hilangnya ion $\mathrm{OH}$ - pada kristal hidroksiapatit menyebabkan kerusakan struktur gigi yang ditandai dengan meningkatnya kekasaran permukaan gigi dan menyebabkan penurunan kekerasan mikro email gigi.

Hasil dalam penelitian ini, setelah dilakukan perendaman dalam asam terjadi penurunan kekerasan mikro permukaan email pada semua konsentrasi. Kristal hidroksiapatit pada email gigi desidui ini terdiri dari garam kalsium fosfat maupun karbonat ${ }^{18,19}$. Salah satu sifat theobromine adalah mampu membentuk garam dengan basa dan garam kalsium yang dapat mengkristal dari air ${ }^{20}$. Paparan asam yang dilakukan pada penelitian ini akan melarutkan kandungan mineral dalam email termasuk $\mathrm{Ca}$ dan $\mathrm{P}$ permukaan yang merupakan salah satu unsur pembentuk garam mineral hidroksiapatit. Akibat larutnya mineral Ca dan $P$ tersebut, ikatan antara theobromine dengan hidroksiapatit di permukaan akan lepas sehingga terjadi penurunan kekerasan.
Lapisan aprismatik email gigi desidui kristal hidroksiapatit yang ada tidak tersusun rapat sebagaimana pada struktur prismatik di bagian bawahnya. Pada struktur email aprismatik tidak terbentuk adanya celah ${ }^{18}$. Apabila ikatan terjadi pada struktur aprismatik, maka kekuatan ikatannya lemah ${ }^{21}$. Lemahnya ikatan ini akan semakin longgar dan mineral hidroksiapatit larut setelah terpapar asam. Hal ini menjadi dasar bahwa pada penelitian ini, ketahanan asam email gigi insisivus desidui tidak tercapai dengan adanya penurunan kekerasan permukaan setelah paparan asam pada semua konsentrasi.

Ukuran kristal, susunan, serta material organik mempengaruhi sifat kimiawi, mekanik, dan fisik email ${ }^{13,22}$. Besar ukuran kristal apatit akan sebanding dengan peningkatan kekerasan $^{16}$, namun European Patent Specification dan Eimar menyatakan bahwa kekerasan bahan kristal berbanding terbalik dengan ukuran rata-rata kristal ${ }^{13,23}$. Semakin besar ukuran kristal maka kekerasan akan semakin menurun. Hubungan ini didasarkan pada pengamatan antarmuka dalam granula kristal yang mengganggu gerakan difusi dan perpindahan antar granula. Komponen organik email, sisa protein, dan air membuat email gigi lebih fleksibel dan lebih lunak dibanding komponen utama berupa kristal hidroksiapatit. Perubahan komponen ini dapat mengurangi daya tahan email terhadap indentasi ${ }^{22}$. Kemungkinan pada konsentrasi $5 \%$, kekerasan yang tinggi menunjukkan komposisi mineral anorganik yang paling banyak serta ukuran kristal paling besar. Apabila terkena asam, maka lepasnya gugus $\mathrm{OH}$ - akan membuat ikatan antar komponen lebih longgar sehingga hidroksiapatit lebih banyak larut dan meninggalkan lebih banyak komponen organik. Hal ini kemungkinan yang menyebabkan terjadinya penurunan 
kekerasan sehingga ketahanan asam tidak tercapai.

\section{KESIMPULAN}

Konsentrasi topikal aplikasi gel theobromine $5 \%$ paling efektif dalam meningkatkan kekerasan mikro permukaan email gigi insisivus desidui.

Topikal aplikasi gel theobromine konsentrasi $1 \%, 2 \%, 3 \%, 4 \%$, dan $5 \%$ tidak dapat mempertahankan email gigi insisivus desidui terhadap asam.

\section{UCAPAN TERIMAKASIH}

Terima kasih kepada Lembaga Pengelola Dana Pendidikan (LPDP) melalui program BUDI DN atas dukungan dana pada penelitian ini.

\section{DAFTAR PUSTAKA}

1. Gunawan, A.H., Pengaruh Perubahan Kristal Apatit, Tingkat Retensi Dan Intrusi Flour Terhadap Kelarutan Email Setelah Perlakuan Larutan Ikan Teri Jengki (S. insularis),Disertasi, Program Doktor Fakultas Kedokteran Gigi Universitas Indonesia, Jakarta,2006.

2. Herisa, H.M., Noerdin, A., dan Eriwati, Y.K., The effect of theobromine $200 \mathrm{mg} / \mathrm{l}$ topical gel exposure duration against surface enamel hardness resistance from $1 \%$ citric acid, Journal of Physics: Conference Series;2017: 884(012009).

3. Alani B.W., Qasim A.A., The effect of topical fluoride products on surface microhardness of enamel of primary teeth (An in vitro study), International Journal of Enhanced Research in Science Technology \& Engineering, 2014;3(9): 147-153.

4. Lee, Mi Ra, Lee, Chung Jae, Park, Ji Hyeon, The Roughness \& Micro-hardness on the Deciduous Teeth according to Formula Milk or Human Milk, International Journal of Clinical Preventive Dentistry, 2011;7(4): 179-88.

5. McCabe, J.F. dan Walls, A.W.G., Applied Dental Materials, edisi ke-9, Blackwell Publishing, Oxford, 2008; $12-14$.

6. Hatrick, C.D, Eakle, W.S, Bird, W.F, Dental materials: Clinical Applications for Dental Assistans and Dental Hygienists, 2nd ed.,Saunders Elsevier: USA, 2011.

7. Sadeghpour, A, A Neural Network Analysis of Theobromine vs. Fluoride on The Enamel Surface of Human Teeth: an Experimental Case Study with Strong Implications for The Production of a New Line of Revolutionary and Natural Non-Fluoride Based Dentifrices, Dissertation Abstracts International, 2007;68 (7).

8. Sulistianingsih, Irmaleny, Hidayat O.T, The remineralization potential of cocoa bean extract (Theobroma cacao) to increase the enamel microhardness, Padjajaran Journal of Dentistry, 2017; 29(2).

9. Nasution, A.I, Zawil C, The comparison of enamel hardness between fluoride and theobromine application, International Journal of Contemporary Dental and Medical Reviews, 2014

10. Haghgou H.R., Haghgoo R., Asdollah, F.M., Comparison of the microhardness of primary and permanent teeth after immersion in two types of carbonated beverages, J of International Society of Preventive and Community Dentistry, 2016;6(4): 342-47.

11. Hamzah, M.M., Semreen M. H., Naddaf, A.R., Anti-inflammatory activity of Achillea and Ruscus topical gel on carrageenan-induced paw edema in rats, Natural Drugs, 2006;63(4): 277-300

12. Jiang, H., Liu, X.Y., Lim, C.T., Hsu, C.Y., Ordering of self assembled nanobiominerals in correlation to mechanical properties of hard tissues, Appl Phys Lett, 2005;86:163901.

13. Eimar H., Tooth Enamel Ultrastructure: Correlation between Composition and Physical Properties, Thesis, Faculty of Dentistry, McGill Univ., Montreal, Quebec, Canada, 2011; 21-34.

14. Nakamoto, T., Simmons, W.B., dan Falster, A.U., Apatite-Forming-Systems: Methods and Products: United States Patent, 2001; 1 - 33.

15. Kargul, B., Ozcan, M., Peker, S., Nakamoto, T., Simmons, W.B., Falster, A.U., Evaluation of Human Enamel Surfaces Treated with Theobromine: a Pilot Study, Oral Health \& preventive dentistry, 2012; 10(3).

16. Amaechi, B.T., Porteous, N., Ramalingam, K., Mensinkai, P.K., Vasquez R.A.C, Sadeghpour, A., dan Nakamoto, T., Remineralization of Artificial Email Lesions by Theobromine, Caries Research, 2013;47: 399-405.

17. Kidd, E.A.M., Fejerskov, O., Dental Caries: The Disease and Its Clinical Management, Blackwell Munksgaard: Oxford, 2003;50-69.

18. Kuroiwa, M, Acid Resistance of Surface - ePrismless' Enamel in Human Deciduous and Permanent Teeth, Showa Univ. J. Med. Sci, 1990;2(1): 31-44

19. Oliveira, M.A.H., Torres C.P., Gomes-Silva, J.M., Chinelatti, M.A., De Menezes, F.C.H., Palma-Dlbb, R.G., Borsatto, M.C., Microstructure and Mineral Composition of Dental Enamel of Permanent and Deciduous Teeth, Microscopy 
Research and Technique, 2010;73: 572-77.

20. Junaidi, L., Sudibyo, A., Hendarti, Penelitian Ekstraksi Theobromine dari Biji Kakao, J.of AgroBased Industry,2007; 24(1): 9-12.

21. Meerbeek, V.B., Munck, D.J., Yoshida, Y.,Inoue, S., Vargas, M., Vijay, P., Van Landuyt, K., Lambrechts, P., Vanherle, G., Adhesion to enamel and dentin: current status and future challenges, Oper Dent, 2003;28(3): 215-35.

22. Shahmoradi, M., Bertassoni, L.E., Elfallah, H.M., Swain, M., Fundamental Structure and Properties of Enamel, Dentin and Cementum dalam Advances in calcium phosphate biomaterials, Biomaterials Science and Engineering, 2014;2: 411-547.

23. European Patent Specification, Compositions comprising theobromine for the prevention of caries, 2010, EP 2533786 B1. 